Maurice A. Deane School of Law at Hofstra University Scholarly Commons at Hofstra Law

Hofstra Law Faculty Scholarship

2004

\title{
Securing Our Children's Future: New Approaches to Juvenile Justice and Youth Violence
}

J. Herbie DiFonzo

Maurice A. Deane School of Law at Hofstra University

Follow this and additional works at: https://scholarlycommons.law.hofstra.edu/faculty_scholarship

\section{Recommended Citation}

J. Herbie DiFonzo, Securing Our Children's Future: New Approaches to Juvenile Justice and Youth Violence, 42 Fam. Ct. Rev. 673 (2004) Available at: https://scholarlycommons.law.hofstra.edu/faculty_scholarship/213

This Book Review is brought to you for free and open access by Scholarly Commons at Hofstra Law. It has been accepted for inclusion in Hofstra Law Faculty Scholarship by an authorized administrator of Scholarly Commons at Hofstra Law. For more information, please contact lawcls@hofstra.edu. 


\title{
THE BOOKSHELF
}

\section{JUVENILE JUSTICE Back to the Future?}

\author{
Gary S. Katzmann, Securing Our Children's Future: New Approaches to Juvenile Justice \\ and Youth Violence. Washington, DC: Brookings Institution, 2002, $444 \mathrm{pp}$.
}

Through much of the 20th century, Americans viewed juvenile delinquents as vulnerable beings in need of redirection, not incarceration. The juvenile court was generally deemed a capable catalyst for whatever change its young charges needed. In 1963, as this era was ending, one knowledgeable observer recorded the then common wisdom: "Few persons would be truculent enough to quarrel with the basic aims of the juvenile court movement, or to take issue with the ideal of regenerating wayward youths without subjecting them to the often rigid, punitive, and distressing vagaries of adult criminal procedure" (Geis, 1963). In the following generation, this worldview was turned upside down. Twice. The excellent collection of essays under review sets the stage for understanding the second, current revolution in juvenile justice.

But first, some history. In the 1960s, the Supreme Court began the process of "constitutionalizing" the juvenile court, furnishing this previously casual venue with the formal trappings of the Fourth, Fifth, and Sixth Amendments. The same concern for procedural fairness that fueled the Warren Court's criminal process revolution convinced the Court that juvenile proceedings were even more wanting. Nor was the Court assured that substantive rehabilitation could emerge from the procedural laxity it condemned. Key decisions such as Kent v. United States (383 U.S. 541, 1966), In re Gault (387 U.S. 1, 1967), and In re Winship (397 U.S. 358, 1970) altered the premises of society's legal treatment of juveniles and set the stage for a reexamination of delinquent juveniles' treatment of society.'

In other words, granting juveniles substantially the same legal rights as adults eased the way to believing - without any social science validation - that juveniles possessed substantially the same moral reasoning capability as adults. The result was the claim that many children should be held as responsible as adults for their deviations from social standards. Thus, while we began the 20th century with the belief that children needed correction, we began the 21 st century persuaded that youthful malefactors are essentially incorrigible.

Dennis the Menace had become Superpredator. The focus of juvenile justice had radically shifted from a baseline examination of the best interests of the child to an overarching concern with public safety, child punishment, and individualized accountability. A slew of juvenile justice measures emphasizing retribution and "emancipation-by-crime"2 formed the core of this punitive turn. Contemporary jurisprudence transformed the juvenile offender from a rehabilitative subject to a retributive object, premised upon the supposedly unstoppable emergence of a cohort of young men, popularly termed "superpredators," whose propensity for violent crime would overwhelm the juvenile court and could be turned away only by a massive increase in incarceration. ${ }^{3}$ In one of the essays included in this book, David M. Kennedy describes the circular reasoning that pervaded the superpredator myth: "Violence is increasing, therefore kids' character must be worsening, therefore worsening character explains the violence" (p. 236).

To be sure, the crime rate ballooned in the 1980s, followed by an equally precipitous bust a decade later. After a period of relative stability from the early 1970 s through 1988 , the juvenile violent crime arrest rate jumped in 1989 to the highest level since the 1960 s (the earliest period for which comparable 
nationwide data are available). This arrest rate then surged upward, climbing $62 \%$ in the years between 1988 and 1994. However, National Crime Victimization Survey (NCVS) data tell a considerably different story. As with the arrest statistics, the rate of victimization increased in the 1990s, although not by as great a proportion as the arrest data. By 1995, however, the victimization measure had leveled to its traditional level. After reviewing the NCVS figures, the 1999 National Report by the Department of Justice, Office of Juvenile Justice and Delinquency Prevention, concluded that "the rate of serious offending as of the mid-1990s was comparable to that of a generation ago" (Snyder \& Sickmund, 1999). Moreover, the decline in arrest rates-the traditional criminological measure-after the early 1990 s was markedly steep. The rate of serious violent crimes, such as rape, sexual assault, robbery, and aggravated assault, committed by juveniles, dropped by one third between 1993 and 1997, ultimately returning to levels comparable to the relatively stable juvenile crime rate between 1973 and 1989. The juvenile arrest rate for murder declined $74 \%$ from its 1993 peak to 2000 , when it reached levels not seen since the 1960s. But knee-jerk retributivism failed to distinguish appropriately between the violent crime and the merely problematic delinquency. In his introduction, Katzmann notes that in 2000 , there were 2.4 million juvenile arrests, but only 99,000 were for violent crime index offenses (homicide, aggravated assault, rape, and robbery; p. 4). The essay by Barbara Fedders et al., points out that nearly eight out of ten youths held in detention in 1997 were not charged with violent index crimes (p. 104, n. 15). All delinquents had become potential superpredators.

As the foregoing brief glimpse into recent history suggests, juvenile justice has endured a major transformation, from the paternalistic hearth of rehabilitation to the punitive heat of adult penology. The pendulum may now be swinging back. Katzmann's collection of essays reveals juvenile justice on the cusp of yet another metamorphosis. Many of the essays point to the emergence of cross-systemic partnerships within an unorthodox expansion of juvenile justice systems integrating public, private, and nonprofit enterprises. The construction of the book mirrors its theme. A collaboration between two NGOs, the Brookings Institution and the Governance Institute, the essays bring into focus the interaction of public prosecutors, defenders, and judges, as well as private universities and researchers employed in the nonprofit sector. The emphasis is on innovative interdisciplinary ventures involving new alliances. For example, the authors of an essay on juvenile prosecution strategies describe efforts to move community policing and prosecution efforts from the original "broken windows" thesis to more complex undertakings in community partnerships (pp. 41-77). A problem-solving paradigm is beginning to replace the respond-and-react model. Prosecutors now choose from a diverse array of legal tools, often developed with community input, such as nuisance actions and injunctions, in a broad-based effort to change the setting and dynamics of juvenile violence before it escalates. Thinking holistically, some prosecutors acknowledge that youthful offenders and victims are frequently part of the same families and that remedies must serve the needs of the whole community.

Defense attorneys also have a role in this broader debate. Without sacrificing their obligation to zealously safeguard their clients' rights, attorneys representing juvenile delinquents encounter "a unique opportunity for positive intervention in the child's life" (p. 92). A child in trouble often manifests deficits in educational and emotional resources, and serving these needs is best accomplished through an multidisciplinary approach. The authors describe one such model program in which

five full-time attorneys-in collaboration with an on-staff psychologist, social workers, and a community outreach worker - currently represent young people in delinquency and youthful offender proceedings as well as school suspension and expulsion proceedings. The social workers and community outreach workers make appropriate referrals to counseling centers, alternative schools, and after-school and job-training programs. They also provide support to the client during a judicial process that, for children and adults alike, usually is difficult, overwhelming, and confusing.

In cases in which a client appears to have a learning disability or behavioral or emotional disorder, the lawyer refers the client to a forensic psychologist who evaluates the client's psychological function and its relationship to the client's current legal problem. (p. 93) 
Community-centered, restorative justice approaches to juvenile justice are championed in several essays, which reinforce the hard lesson that stricter sentencing and shifting delinquents to adult courts do not succeed in reducing crime or restraining recidivism. ${ }^{4}$ Several of the essays focus on juvenile justice innovations in Boston. One of these describes the success of the "Ten Point Coalition," combining the efforts of police and clergy in confronting lethal gang violence (pp. 204-212). Another recounts a joint project of police and probation officers (two groups that historically have rarely worked together) to monitor high-risk probationers in the evening in their own communities (pp. 175-192). "Operation Ceasefire" featured working groups of federal and local law enforcement officers; representatives of the probation, parole, and youth corrections departments; and gang outreach workers, all centered on a simple mission: persuading Boston's gang youth to turn in their weapons (pp. 233-250). The surprising and rapid success of that effort provides another chapter in the emerging consensus shifting resources from reactive to proactive measures. In a related vein, the essay about the changing role of the judiciary called for increasing reliance on alternative dispute resolution in juvenile court, as well as restorative justice approaches and greater coordination in judicial efforts generally (pp. 128-131). The creation of unified family courts would be the most salient reform in this area, the authors assert; but even coordinating the functions of the present courts that have a role in family issues would help juveniles and their families in crisis.

The ham-handedness of the effort to fight the imaginary generation of superpredators is further illustrated in an essay on the importance of juvenile classification (pp. 147-171). The author, Gerald G. Gaes, was a longtime director of the Office of Research at the Federal Bureau of Prisons. He argues that the efficiency of juvenile placement decisions would be greatly enhanced if institutions employed more rigorous classification procedures. A more nuanced approach would enable the placement personnel to distinguish between historical and status variables (such as criminal record and family status), which are difficult or impossible to alter, and the "dynamic" variables (such as independent living skills, educational level, and substance abuse), which can be modified by targeted intervention. Gaes's project sounds sensible, but the statistics do not yet bear him out. As he concedes, the results of a metaanalysis of program interventions on juvenile offenders are only modestly encouraging. "Untreated" youth relapsed at a rate of $50 \%$; targeted treatment reduced the rate of recidivism only to $44 \%$ (p. 164).

The importance of institutional coordination across routine work boundaries is stressed in two essays: Francis X. Hartmann focuses on community-based strategies that decentralize treatment of issues of fear and disorder in order to facilitate more effective problem solving (pp. 262-285). Hartmann stresses the role of a "powerful neutral convener" as a catalyst holding together community players with conflicting or competing interests, keeping them focused on the targeted issue. The requisite community leader need not have a conventional position of authority but must have informal political influence sufficient to induce other local leaders to work productively and cooperatively. Mark $\mathrm{H}$. Moore emphasizes the creation of institutional "networks of capacity" (pp. 338-381). Viewing youth violence as a managerial challenge, Moore explores the process of taking "the uncoordinated operations of different agencies and turn[ing] them into a more or less coherent and well-understood strategy for action that can be implemented successfully" (p. 348).

In a very useful concluding essay (pp. 386-403), Katzmann summarizes the emerging paradigm for juvenile justice. He outlines the new types of partnerships, both ongoing and envisioned: working groups involving law enforcement officers, school personnel, and mental health professionals; the new prosecutor as primarily a community problem solver; defense attorneys who participate in formulating public policy; courts recognizing that they are integral to the delivery of social services; probation officers who leave their offices to actively involve themselves in the streets and lives of their probationers; aftercare programs organized as part of the continuum of corrections; and integrating nonprofits, faithbased organizations, and the private sector into the solutions for youth violence.

These efforts may indeed signify a second major transformation in juvenile justice, this one a sensible turn to constructive and therapeutic approaches engaging the real lives of troubled and troubling juveniles. The early returns are encouraging. In a key sense, however, what these essays presage is a return to one of the original core concepts of juvenile justice reform. For example, the essay on the 
enhanced role of the modern juvenile defense attorney highlights the benefits of a cross-disciplinary approach:

With a detailed assessment of a young person's psychological and social history, an attorney can help the judge focus not only on the young person's offense but on the whole person. Moreover, in pinpointing the problems that led to the misdeed, the lawyer often can enlist the judge in the effort to save the child from a cycle of incarceration and recidivism. (p. 93)

The goals of considering the offender more than the offense and of saving the child from the vicious trap of a swinging prison door resonate deeply in my historically attuned ears. They were precisely the aims of the founders of the juvenile court a century ago. ${ }^{5}$ A revolution usually refers to a dramatic transformation. But revolutions sometimes-at least in some aspects-come full circle. The essays in this volume provide hope that in our second century through juvenile justice, we might improve both the process and, much more important, the lives of our children and their communities.

\section{-J. Herbie DiFonzo}

Professor of Law, Hofstra Law School

\section{NOTES}

1. This point has been made often, most recently and quite well in Feld (2003).

2. This term refers to the ironic process by which the severity of an offense is deemed a marker for the child's maturity level and emancipation into adulthood. See DiFonzo (2001), quoting a judge's words upon sentencing a 15 year-old boy to life imprisonment for murder: "I do not perceive you to be a child . . [y] [our monstrous act made you an adult." This viewpoint is also reflected in the political campaign catchphrase "adult crime, adult time" (Bradsher, 1999; Brummel, 1998).

3. Lest the reader suspect I exaggerate the rhetorical dogmatism, let me quote from the prime exponent of the superpredator thesis, John J. Dilulio Jr., writing in 1996:

The "deinstitutionalization" of juvenile criminals (most were never institutionalized in the first place) is an ongoing social disaster. Given the fact that there will be about thirty-five million males age seventeen or under in the population by the year 2010-roughly five million more than there were in 1990, and a larger fraction of boys than ever before growing up as the abused and neglected sons of fatherless, godless, and jobless homes and neighborhoods - the worst is most definitely yet to come.

Dilulio, who was a professor at Princeton University at the time and then became an official in the Bush administration, has now admitted that his prediction of a wave of violence driven by juvenile superpredators was mistaken (Becker, 2001). Franklin Zimring, a respected criminologist and Dilulio critic, responded to the latter's concession with some acerbity: "His prediction wasn't just wrong, it was exactly the opposite... . His theories on superpredators were utter madness" (Becker, 2001).

4. The failures of both lengthier detention and waiver to criminal court as methods to curb juvenile delinquency have been thoroughly documented (see, e.g., DiFonzo, 2001; Redding, 2003; Shefi, 2003).

5. See, for example, the seminal article by one of the early Juvenile Court Judges (Mack, 1909).

\section{REFERENCES}

Becker, E. (2001). As ex-theorist on young "superpredators," Bush aide has regrets. The New York Times, February 9, pp. A19.

Bradsher, K. (1999). Michigan boy who killed at 11 is convicted of murder as adult. The New York Times, November 19, pp. Al.

Brummel, P. (1998). Doing adult time for juvenile crime: When the charge, not the conviction, spells prison for kids. Law \& Inequality Journal, 16, 541 . 
DiFonzo, J. H. (2001). Parental responsibility for juvenile crime. Oregon Law Review, 80(1), 13, 32-37.

Dilulio, J. (1996). The truth about crime and welfare. First Things, 65, 31-35, also available at http://www. firsthings.com/ftissues/ft9608/opinion/diiulio_response.html (accessed June 21, 2004).

Feld, B. (2003). The politics of race and juvenile justice: The "due process revolution" and the conservative reaction. Justice Quarterly, 20(4), 772-778.

Geis, G. (1963). Contributing to delinquency. St. Louis Urban Law Journal, 8, 60.

Mack, J. (1909). The juvenile court. Harvard Law Review, 23, 104.

Redding, R. (2003). The effects of adjudicating and sentencing juveniles as adults: Research and policy implications. Youth Violence and Juvenile Justice, 1(2), 128-155.

Shefi, E. (2003). Waiving goodbye: Incarcerating waived juveniles in adult correctional facilities will not reduce crime. University of Michigan Journal of Law Reform, 36, 653-689.

Snyder, H., \& Sickmund, M. (1999). National Report 130. Office of Juvenile Justice and Delinquency Prevention, U.S. Department of Justice, Juvenile Offenders and Victims. 
Copyright of Family Court Review is the property of Blackwell Publishing Limited and its content may not be copied or emailed to multiple sites or posted to a listserv without the copyright holder's express written permission. However, users may print, download, or email articles for individual use. 